This is an Accepted Manuscript of an article published by Taylor \& Francis in Restorative Justice on 13 December 2017, available online: http://www.tandfonline.com/doi/full/10.1080/20504721.2017.1390999.

\title{
Restorative Justice for Victims: Inherent Limits?
}

\section{Gerry Johnstone}

\begin{abstract}
Campaigners for restorative justice challenge assumptions that we should handle crime by punishing those responsible and that this is a task for the authorities. They suggest that we should deal with criminal behaviour by encouraging those responsible to repair the harm they have caused and that those who cause and suffer harm should be at the centre of deliberation and decision-making. There is little sign of such a fundamental shift in social assumptions occurring. This paper explores 'internal' obstacles to achieving this goal: structural weaknesses in the case for restorative justice. The focus is on contradictions in the way the campaign for restorative justice has thought about the role of victims in restorative encounters. Involvement of victims is crucial for two quite different reasons: they have an essential role to play in the reform of offenders and they need to be involved to benefit from the healing effects of restorative encounters. Tensions between these two ways of thinking about the rationale for victim involvement have been insufficiently acknowledged. This hampers the campaign for restorative justice from achieving its loftier ambitions.
\end{abstract}

Key words: restorative justice, victims, offender reform, healing.

\section{Introduction}

In modern society it tends to be taken for granted that we should deal with incidents of criminal behaviour by punishing those we deem responsible for them, i.e. by inflicting something unpleasant upon the 'authors' of crimes. We also generally assume that this is a task for the authorities in society. So, whilst the question of how criminal behaviour should be dealt with is debated intensely within modern societies, discussion usually proceeds from these fundamental assumptions. We tend to argue about the ends to which punishment should be directed (retribution, deterrence, reform of the offender); about appropriate methods of punishment (death, imprisonment, community service, etc.); about how severely or leniently we should punish offenders; and about the values that should guide and constrain our penal practices (legality, justice, security, compassion, civilization, etc.). What is distinctive about the campaign for restorative justice is that, rather than contribute to such discussions, it seeks 
This is an Accepted Manuscript of an article published by Taylor \& Francis in Restorative Justice on 13 December 2017, available online: http://www.tandfonline.com/doi/full/10.1080/20504721.2017.1390999.

to challenge the basic assumptions around which they revolve. ${ }^{1}$ The campaign seeks to push punishment to the margins of social life (Braithwaite, 1999). It suggests that we should deal with criminal behaviour by encouraging those responsible for it to repair the harm their behaviour has caused to other people and to relationships. And it proposes that those people who are directly harmed by criminal behaviour, and those who cause this harm, should play a central role in deliberating and deciding what harm has been caused and what the offenders should do to discharge their obligations to try to repair this harm.

If we evaluate the campaign for restorative justice in terms of the extent to which it has succeeded in achieving this lofty aspiration, i.e. changing core assumptions in modern society concerning the way criminal behaviour should be dealt with, it has arguably not been very successful. Such an assessment will no doubt surprise - and perhaps be contested by those restorative justice campaigners who can point to an explosion of interest in restorative justice, and indeed in the use of restorative justice practices, in recent decades. Whilst the very concept of restorative justice was unfamiliar in the 1990s (Sullivan et al, 1998), as Howard Zehr points out:

Academics now study and debate it at conferences and in a rapidly growing literature in various languages; governments sometimes finance and even advocate it; a growing number of communities and countries throughout the world are implementing it; and increasing numbers of people are seeking to make careers in the field (Zehr, 2015: 229).

Yet, if instead of documenting this activity we ask how effective it has been in pushing punishment to the margins of social life - in dispelling our elementary assumptions about how criminal behaviour should be dealt with - there is arguably much less to celebrate. David Garland's assessment in 2001 of the impact of restorative justice upon criminal justice policy and practice still requires little modification. In The Culture of Control Garland mentions restorative justice as one of 'a deluge of new programmes and policy initiatives' that have appeared since the 1970s in the wake of a partial collapse in confidence in established approaches to crime control and criminal justice (2001: 104). Unlike some more radical

\footnotetext{
${ }^{1}$ The campaign for restorative justice is distinctive, but not unique, in this respect. In the nineteenth and twentieth centuries, these assumptions were also challenged by those who argued that criminal behaviour was a symptom of some underlying disorder which should be treated (see Johnstone, 1996).
} 
This is an Accepted Manuscript of an article published by Taylor \& Francis in Restorative Justice on 13 December 2017, available online: http://www.tandfonline.com/doi/full/10.1080/20504721.2017.1390999.

projects (such as abolitionism) which have 'captured the imagination of academics and radicals but had little sustained impact upon government thinking and institutional policy’ (ibid), restorative justice has clearly had an influence upon contemporary policy and practice. But, that influence has been limited: restorative justice has 'been allowed to operate on the margins of criminal justice, offsetting the central tendencies without much changing the overall balance of the system' (ibid). To the extent that this assessment is accepted as accurate today, it must be disappointing for advocates of restorative justice who envisage a future in which it is the practice of state punishment that operates on the margins of criminal justice, where the priority of criminal justice systems is to repair the harm caused by crime, and where those who cause and are affected by the harm of crime are at the centre of discussion and decision-making on what should be done (Braithwaite, 1999; Walgrave, 2008).

What can be done about this? One option, of course, is to modify the aspirations of the campaign for restorative justice. Perhaps the assumptions prevailing in our societies about how to handle criminal behaviour are too deeply rooted to shift easily. Maybe it is more realistic simply to make restorative justice practices available as widely as possible and to secure governmental and popular support for these practices. The goal of bringing about a deeper paradigm change can be retained as a long-term aspiration. But in the meantime, the energies of the campaign for restorative justice are perhaps better focussed on achieving more realistic objectives. This seems to be the option which the campaign for restorative justice has adopted in practice.

An alternative option is to continue to pursue seriously the early aspirations of the campaign for restorative justice: to continue efforts to undermine the basic presuppositions of public discourse about how to deal with criminal behaviour. If this option is to be pursued, an urgent task is to identify the obstacles to achieving such aspirations. Schematically, these obstacles can be divided into two sorts: external and internal.

External obstacles might include the fact that the assumptions which the campaign for restorative justice seeks to dispel are instilled in people at an early age and thereafter constantly reinforced. As a result they require an air of obviousness; as Zehr puts it, they seem 'natural and inevitable' (2015: 101). To challenge these assumptions seems to be going against common sense, and that is always difficult. Perhaps another external obstacle is that so many people have a vested interest in maintaining the institutional machinery that has been built upon the assumptions that offenders must be punished and that the state must take 
This is an Accepted Manuscript of an article published by Taylor \& Francis in Restorative Justice on 13 December 2017, available online: http://www.tandfonline.com/doi/full/10.1080/20504721.2017.1390999.

charge of this process. If, as campaigners for restorative justice (drawing upon the language of Nils Christie, 1977) frequently assert, the state and its professionals have stolen the people's conflicts, surely they have a vested interest in keeping them. Jobs and statuses are at stake.

Along with such external obstacles there may, however, be internal obstacles. What I have in mind here are structural weaknesses in the case for restorative justice. These can include vagueness and incoherence about basic matters such as what restorative justice is and what it seeks to achieve (von Hirsch et al, 2003: 22-3; Johnstone, 2007). And, they can include contradictions, ambiguities, and inconsistencies in the discourses, arguments and rhetoric of the campaign for restorative justice (cf. Pavlich, 2005). This paper forms part of a broader body of work which seeks to expose such internal obstacles to the development of restorative justice. Hence, its goals is critical, but this is not a 'hostile critique' intended to undermine the case for restorative justice. Rather, it is more a 'sympathetic critique', designed to identify and point to ways of correcting inherent limitations of restorative justice thinking, with a view to improving the chances of the goals of the campaign for restorative justice being realised. The focus here is on the way the campaign for restorative justice has thought about the role of victims in restorative justice processes. Such a focus is especially relevant following the coming into force (in November 2015) of the European Union Victims' Directive which - with the aim of strengthening the rights of victims of crime cautiously endorses restorative justice services provided they are used only if they are in the interest of the victim. ${ }^{2}$ Given the cautious nature of this support for restorative justice 'services', if the restorative justice movement is to flourish in an environment where victims' rights are increasingly emphasised, it is important to clarify the motives for involving victims in restorative justice interventions and to be frank about what restorative justice cannot precisely because it is restorative justice - do for crime victims.

\section{Involving victims}

\footnotetext{
${ }^{2}$ See article 12 of Directive 2012/29/EU of the European Parliament and of the Council; text available at http://eur-lex.europa.eu/legal-

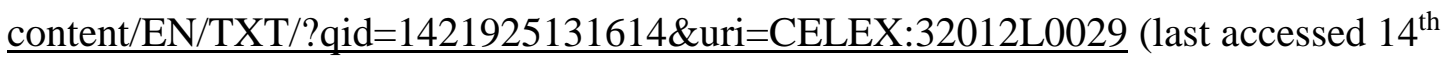
November 2016). For background see Ezendam and Wheldon (2014). 
This is an Accepted Manuscript of an article published by Taylor \& Francis in Restorative Justice on 13 December 2017, available online: http://www.tandfonline.com/doi/full/10.1080/20504721.2017.1390999.

Almost everybody working in the field of restorative justice agrees that involvement of victims in the process is essential. ${ }^{3}$ What is less often asked is precisely why the involvement of victims is so crucial. There are, in fact, two quite different answers to this question. These answers are in tension with each other and becoming more aware of this tension helps us to see an important obstacle to the further proliferation of restorative justice.

One reason why restorative justice needs victims to participate is that it is based on the idea that offenders, if they are to become fully conscious of the fact that their offending behaviour does cause actual harm to real people, need to meet face-to-face with their victims. A key idea is that offenders benefit by hearing real victims explain, first hand, how their lives have been affected by the offence committed against them. The literature of restorative justice is replete with stories about how meeting with their victims, and hearing directly about their suffering, instigated a fundamental shift in the offender's attitudes and conduct. ${ }^{4}$ The literature tells us that most offenders want to avoid recognising and facing the harm they have done and the pain they have caused. So, whilst they are seldom affected emotionally by a dressing down from a judge in which the emphasis is upon how they have broken the law and are a menace to society, when offenders hear their victims tell them about their suffering offenders tend to be deeply moved and often experience shame and remorse. If carefully managed, it is suggested, this emotional transformation can in turn can result in offenders making a firm commitment to try to repair the harm they have done and to refrain from doing things that cause further suffering to more people. Hence, victims are required for restorative justice because they have a crucial role to play in the reform of offenders. As David Cayley puts it, based on extensive interviews with early restorative justice advocates and practitioners:

if they [offenders] are going to reform, their victims hold an important key. They carry with them the evil that offenders have done, and they are uniquely able to make offenders aware of this evil. No one is likelier to kindle repentance in an offender's heart (1998: 229).

Cayley illustrates this point with a quotation from Jim Cavanagh - a prisoner-turned-minister:

\footnotetext{
${ }^{3}$ For an overview, see Dignan (2005).

${ }^{4}$ For a useful overview see Cayley (1998: chapter 12).
} 
This is an Accepted Manuscript of an article published by Taylor \& Francis in Restorative Justice on 13 December 2017, available online: http://www.tandfonline.com/doi/full/10.1080/20504721.2017.1390999.

I know from past experience that one of the hardest things for an offender is to face the victim they hurt, because they feel bad. They would rather not see that person. And, to me, they should be confronted with the victim, and the victim should be able to ... say, "Do you know how bad you hurt me? This is what I feel like.” Because then they become conscious of the feelings the victim is going through; otherwise, they're not in touch with the reality of what the victim is suffering and has felt (ibid: 229-30).

The second, quite different, reason for victim participation being crucial to restorative justice is simply that that one of the purposes of restorative justice is to heal victims. And, for victims to be healed through restorative justice, they need to participate in victim-offender encounters (Strang, 2002). It is through participation in such encounters that many important needs of victims can be met. To quote from the introduction to a recent book on victims and restorative justice:

The encounter with the offender allows victims to receive the offender's acknowledgement, to express their anger concerning the impact of the offence, to receive answers to questions and to see the offender being honest (both through words and body language). The encounter would provide victims with the possibility to find symbolic forms of reparation, such as apologies and remorse, or to see the offender changing or doing something about his/her problem (Bolivar et al, 2015: 3).

In simple terms, restorative justice can benefit victims - it can help them recover from a traumatic experience - but it can only deliver these benefits if victims actually participate in it.

So, the involvement of victims is required by restorative justice for two very different reasons. First, victims have a vital role to play in a process designed to reform offenders. Second, part of the point of restorative justice is to bring healing and an experience of justice to victims, but in order to achieve that it is necessary for victims to take part.

\section{$2 a$ Why victims might participate in restorative justice}

Let us turn now to a rather different question: not why restorative justice needs victims to take part, but why victims might be willing to participate in restorative justice. Again, schematically, we can distinguish two different reasons. First, and most obviously, victims might participate in order to gain the experience of healing and justice which restorative justice promises. If victims are to participate for this reason they need to (i) feel a need for an 
This is an Accepted Manuscript of an article published by Taylor \& Francis in Restorative Justice on 13 December 2017, available online: http://www.tandfonline.com/doi/full/10.1080/20504721.2017.1390999.

experience of healing and justice and (ii) be confident that participation in a victim-offender encounter will help meet this need.

The second reason victims might have for participating is that, by doing so, they might make a vital contribution to the reform of the offender. Victims might be interested in this for a variety for reasons. Some might be motivated by pure altruism or, to use Bolivar at al's term, 'pro-social desires' (Bolivar at al, 2015: 3). They may see participation in restorative justice as a way of saving somebody from a bad life and helping to ensure that others do not become victims of the offender and suffer in the way they have suffered. In some cases, such pro-social desire may be underpinned by religious beliefs. For others, the motivation may be more subtle. For many victims, one way of recovering from the trauma they have suffered - where it is difficult to make sense of why they have suffered it - is to try to make sure that some good comes of it.

\section{$2 b$ Why victims might not participate in restorative justice}

On the other hand, there are quite a number of reasons why crime victims might not participate in restorative justice.

Probably the most common reason for victim non-participation is that they are not provided with the opportunity to do so. This, in turn, could be for different reasons. On the one hand, the offence committed against them might not be processed (or even formally defined) as a crime. On the other, the offence might be defined and processed as a crime, but a restorative justice intervention is not organised. We will look at these a little more closely because, in both cases, they point to significant inherent limitations of restorative justice.

We know from victim surveys and studies of the 'dark figure' of crime that the majority of ‘criminalisable events' are, for various reasons, not defined or processed as actual crimes (Hulsman, 1986; Coleman and Moynihan, 1996). It is important to recognise that, in principle, this is not an insurmountable obstacle to some victims benefitting from restorative justice. It is possible to imagine community-based restorative justice services existing to which anyone who is harmed by a 'criminalisable event' could go to seek a restorative intervention. Provided those running the service could then locate the perpetrator of the harmful act and persuade them to take part voluntarily in a restorative justice process, a restorative intervention would be possible. Of course, in practice we might expect very few perpetrators to take part. But, some - out of a desire to repair the harm they have caused or to 
This is an Accepted Manuscript of an article published by Taylor \& Francis in Restorative Justice on 13 December 2017, available online: http://www.tandfonline.com/doi/full/10.1080/20504721.2017.1390999.

heal a relationship that their behaviour has damaged - might agree. ${ }^{5}$ Yet, in practice, such services are seldom organised or offered. ${ }^{6}$ The reason for this seems to be that most restorative justice schemes operate from or through services (such as the police or probation services) whose primary function is to work with 'offenders', i.e. people who have to some extent been processed as offenders (either arrested, charged, cautioned, or convicted). So, unless a 'criminalisable event' is formally defined as a crime, and the perpetrator formally processed as a suspect or offender, there is little likelihood of a victim-offender encounter being offered to a victim.

Even where an offender is processed to some extent by the criminal justice system, the chances of a restorative justice process being organised are relatively slim. In practice, most restorative justice schemes tend to be focussed upon specific types of offence or specific types of offender. For instance, a police service might decide to use restorative justice as a way of tackling a particular problem, such as an outbreak of shoplifting. ${ }^{7}$ Or, there may be a policy of using restorative justice only for certain types of offences (e.g. property offences) and to exclude other types of offences (e.g. offences involving violence). Unless you are the victim of the type of offence targeted, you are unlikely to be offered restorative justice. Or, quite commonly, a restorative justice scheme might be targeted at a particular category of offender, such as young offenders. In this case, your chances of being offered restorative justice as a victim depend upon something purely fortuitous: the age of your offender.

Similarly, most restorative justice schemes will have conditions which an offender must satisfy before being offered restorative justice. Most obviously, it is almost invariably a condition of being offered restorative justice that an offender admits involvement in a criminal offence. Again, as a victim, your chances of being offered restorative justice as a victim depend upon something purely fortuitous: whether your offenders admits or denies involvement in the offence.

All of these limitations are, of course, fairly obvious and well-known to advocates and practitioners of restorative justice. But, less thought is given to their nature and implications. They arise from the fact that, in practice, restorative justice schemes tend to be based within

\footnotetext{
${ }^{5}$ For an interesting suggestion to this effect, see Bennett (2008: 1-10).

${ }^{6}$ But see the Zwelethemba project described by Froestad and Shearing (2007).

${ }^{7}$ See, for example, http://turningpointjustice.com/About (last accessed 20th October 2016).
} 
This is an Accepted Manuscript of an article published by Taylor \& Francis in Restorative Justice on 13 December 2017, available online: http://www.tandfonline.com/doi/full/10.1080/20504721.2017.1390999.

services that handle offenders and that the first questions that are asked, when deciding whether a particular case is suitable for restorative justice, tend to be offender-based questions. As Arlene Gaudreault, ${ }^{8}$ looking at restorative justice from the perspective of an advocate of victims' rights, puts it:

There is a tendency to forget that "restorative" action in its various forms rarely springs from the wishes of victims themselves or victim support organizations. Most of the time, the action centres on the offender. It is often set in motion by services that work with offenders - minor and adult alike - in the context of probation, alternatives to incarceration or parole. ... Although responding to the needs of victims is not absent from their concerns, it will not be at the forefront (Gaudreault, 2005: 5).

The implication is that although in theory restorative justice seeks to restore both offenders and victims, and does not regard one of these aims as having priority over the other, in practice restorative justice schemes tend to be based in services whose traditional and still primary mission involves working with offenders. Inevitably, no matter how sincere and earnest the commitment to healing victims is, efforts to secure victim participation tend to follow decisions about whether or not the offence or offender is suitable for restorative justice. $^{9}$

We will turn now to look at some reasons why a victim, who is offered the opportunity to participate in a restorative justice process, might decline to do so. The possibilities here include: (a) they are not persuaded by the reasons they are given for participating and (b) whilst they can see some benefits, they also have reasons for not participating which outweigh the perceived benefits of participating.

With regard to 'a', let us look at a fairly typical list of 'benefits' to victims suggested by a provider of restorative justice interventions. Restorative Justice Victoria (in Canada) lists the benefits for victims as follows:

Victims get the opportunity to:

- Obtain information - ask questions of the offender to understand what happened and the underlying reason for the offence

\footnotetext{
${ }^{8}$ President, Association Québécoise Plaidoyer-Victimes.

${ }^{9}$ For a detailed discussion of concerns within the victims' movement about restorative justice being over-sold as a victim-centred approach to crime, see Green (2007).
} 
This is an Accepted Manuscript of an article published by Taylor \& Francis in Restorative Justice on 13 December 2017, available online: http://www.tandfonline.com/doi/full/10.1080/20504721.2017.1390999.

- Express the impact - directly tell the person who caused them harm how their actions have affected them

- Be empowered - be part of the decision making process regarding what will happen next and how to deal with the aftermath of crime

- Obtain restitution - be able to ask for restitution, both concrete and symbolic

- Have control over the process and outcome - participate how they want and put forward requests for restitution etc. ${ }^{10}$

There is little doubt that many crime victims would welcome these opportunities, or at least some of them. Hence, if they can be convinced that a restorative justice process will provide these opportunities, and that there are no significant dangers or downsides, there is a strong chance of them responding positively to an invitation to participate.

However, nor can there be any doubt that many victims, perhaps the majority, have little desire for such opportunities. The assumption - which is treated as almost axiomatic in restorative justice discourse - that victims desire the opportunities which victim-offender encounters provide, is put in question by research which suggests that the vast majority of victims say they do not want any information, advice or support from the state or from other sources (e.g. Ministry of Justice, UK, 2012: 9). These issues clearly need more research, but it seems plausible to suppose that the majority of victims do not identify themselves as sufferers from trauma and see themselves as in need of healing. Rather it seems just as likely that many victims identify themselves simply as people who have had certain of their rights violated and that what they desire is 'justice’ as conventionally conceived: the offender should be punished and the state should take charge of this process. ${ }^{11}$

${ }^{10}$ https://rjvictoria.wordpress.com/about/how-our-clients-benefit/, emphasis in original (last accessed $20^{\text {th }}$ October 2016).

${ }^{11}$ There is now a significant amount of empirical research into victims' views and reactions to participation in restorative justice (see, for examples, Angel et al, 2014; Choi et al, 2012; Poulson, 2003; Strang et al, 2006; Shapland et al, 2011: 139-148). Amongst the findings of this literature are that the majority of victims who participate in restorative encounters have a satisfactory experience; a minority report an unsatisfactory experience and this is often due to their sense that the focus of the encounter was on achieving a beneficial outcome for the offender (see Rossner, 2017: 979-981 for a brief overview). This research is, understandably, conducted with subjects who have agreed to participate in restorative justice encounters. 
This is an Accepted Manuscript of an article published by Taylor \& Francis in Restorative Justice on 13 December 2017, available online: http://www.tandfonline.com/doi/full/10.1080/20504721.2017.1390999.

Even where victims do feel traumatised, are receptive to the opportunity to participate in an intervention that might help them recover, and are persuaded that a victim-offender encounter might so help them, there may be reasons for not participating that outweigh these factors. First, participation in a victim-offender encounter is burdensome. In a straightforward sense, simply taking part in the encounter (including going through the preparation process) imposes burdens on the victim that they may be unwilling to bear. In addition, victims may be quite reluctant to accept any responsibility for the fate of the offender. Restorative justice advocates often take it for granted that, in the aftermath of a crime, the victim will want to be part of the decision-making process concerning what happens next. However, it is just as likely that many victims would prefer to delegate this decision-making process wholly to officials and professionals. Rather than experiencing this as the state stealing their conflict (cf. Christie, 1977 - whose words on this have become a mantra of the restorative justice movement), it is just as plausible that many victims would experience this as the state fulfilling its proper function. Second, many victims, when they hear about restorative justice, do form the impression that it is primarily about meeting the offender's needs (Mika et al, 2004). The fact that most schemes are organised by or through services that work primarily with offenders does little to dispel this idea. And, in practice, members of these organisations, however well-meaning, have little experience of working with crime victims and this may make their contacts with them rather awkward. As Gaudreault suggests, they may have relatively little understanding of 'the phases of criminal victimization, post-traumatic stress and the way victims work through their loss and grief' (2005: 5). And, many

... are uncomfortable dealing with victims. Ill prepared to meet their expectations, taken off guard by their reactions, they feel that they are playing conflicting roles and are poorly equipped (ibid).

\section{Inherent or incidental}

If these obstacles to victim participation are to be overcome, it is crucial to understand their nature. An important basic question is whether they are inherent to restorative justice. If so, what would be required to overcome them is not simply more effort on the part of restorative

What such research cannot tell us, of course, is about why victims (who may well benefit from participation) do not in fact take part. 
This is an Accepted Manuscript of an article published by Taylor \& Francis in Restorative Justice on 13 December 2017, available online: http://www.tandfonline.com/doi/full/10.1080/20504721.2017.1390999.

justice practitioners, more refinement of programmes, and so on. Rather, some core ideas of restorative justice may require fundamental rethinking.

In order to explore this issue in a little more depth, we will briefly consider a different 'alternative’ way of thinking about providing justice and healing for victims of crime: 'parallel justice'. Parallel justice is advocated by the National Center for Victims of Crime, USA, and in particular by its former Executive Director Susan Herman (Herman 1999, 2010). Much of what Herman has to say about justice for crime victims is similar to what is found in the discourse of restorative justice. ${ }^{12}$ She suggests that in one year there were 31 million crime victims in the USA (1999: 2). These victims

... rarely emerge unscathed by the experience. Many suffer continuing trauma without the services and support they need to help them reassemble their lives. Victims of crime suffer lowered academic performance, decreased work productivity, high medical expenses and severe loss of confidence. Mental illness, suicide and drug and alcohol abuse are also far more common among crime victims than the general public (ibid: 3).

Herman goes on to point to two significant developments, that have occurred in recent decades, which go a long way towards recognizing and responding to the needs of crime victims. First, there are victim services: the emergence of a range of services - from emergency practical assistance to day care, housing and long-term counselling -which help ease the trauma that victims have suffered. The other is the emergence of victims' rights: to information about the criminal justice system and to participate meaningfully in decisions about the crime they experienced (ibid: 3-5).

In general, these are developments that campaigners for restorative justice both welcome and seek to further (although they are wary of granting rights to victims to participate in 'traditional' criminal justice decisions, such as sentencing decisions - see Wright 1996). Yet, whilst Herman regards restorative justice as having great potential for benefitting victims, she suggests that it does not provide everything that victims' advocates have been asking for, and that this explains why restorative justice has not 'been particularly championed by the victims' movement' (ibid: 5-6).

\footnotetext{
12 Howard Zehr cites Herman’s thoughts on parallel justice as complementary to his own thoughts on restorative justice (see Zehr, 2015: 319).
} 
This is an Accepted Manuscript of an article published by Taylor \& Francis in Restorative Justice on 13 December 2017, available online: http://www.tandfonline.com/doi/full/10.1080/20504721.2017.1390999.

Herman points out that restorative justice leaves out most victims (ibid: 6-7). Also, importantly, she argues that whilst restorative justice goes a little way towards meeting the needs of victims, victims have extensive needs which cannot be met through restorative justice (at least as currently conceived):

Repairing the harm is often far more complicated than apologies and restitution and relationship-building. It can require long-term sophisticated counseling, assistance with safety planning, relocation and any number of services required to rebuild a lifeemergency day care for the parent who needs to get a job to handle new crime-related expenses, substance abuse treatment for the traumatized victim who has turned to drugs, a companion for the victim now too afraid to leave home or go to the store alone, employment counseling or training for victims who no longer can perform their old jobs. Harm caused by an offender in a moment can impact a lifetime and the reparation can have very little to do with an ongoing relationship with an offender or a community (Herman, 1999: 7).

Crucially, Herman suggests that the limitations of what restorative justice can do for victims are inherent to it. Restorative justice is limited to the resources that offenders and 'communities of stakeholders' can bring to the table. What they can bring is empathy, restitution and relationship building; but victims need far more than that (ibid: 8). As long as restorative justice interventions are tied to the criminal justice process, no matter how much they differ from more conventional interventions within that process, they cannot truly respond to victims’ needs.

Accordingly, Herman advocates and asks us to imagine a society in which there was a parallel system of justice for crime victims. We need to establish a path to justice for victims, underpinned by a full range of governmental services, which is decoupled from the administration of justice for offenders (ibid: 9).

The feasibility and desirability of such a system is not the focus of this paper. ${ }^{13}$ Rather, by showing what - for a victims’ advocate - a system which could provide justice

\footnotetext{
${ }^{13}$ I have briefly considered Herman's ideas about parallel justice in order to highlight that some of those whose point of departure is to bring about a reform that will benefit victims tend to regard restorative justice as limited in its potential, precisely because this is not its
} 
This is an Accepted Manuscript of an article published by Taylor \& Francis in Restorative Justice on 13 December 2017, available online: http://www.tandfonline.com/doi/full/10.1080/20504721.2017.1390999.

and healing for crime victims would look like and how it would be positioned, this paper seeks to raise important questions not only about whether restorative justice does, but about whether it could make a significant contribution to the provision of justice and healing for victims of crime (cf. Gavrielides, 2014).

\section{Conclusion}

Restorative justice interventions have multiple goals (von Hirsch et al, 2003). Two of the core goals are helping offenders to become really aware of the harm their actions have caused and helping victims to recover from the trauma they have suffered as a result of a crime. Victims have a role to play in achieving both of these objectives. On the one hand, by telling offenders about the harm they have suffered, they can make offenders more aware of this harm. On the other hand, victims can obtain the healing effects of restorative justice by participating in restorative encounters with offenders. It is possible that both of these goals can be achieved simultaneously. However, restorative justice campaigners have tended to ignore the tensions that exist between these two goals. This tends to make the campaign oblivious to the complex issues, such as how the positioning, design and conditions of restorative justice programmes can indicate a prioritisation of one of these goals (reform of offenders) over the other (healing of victims). If the campaign for restorative justice is to enjoy more success, tensions such as these need to be acknowledged and better understood and efforts need to be made to resolve them. This may require significant modification and refinement of the discourse of restorative justice.

\section{References}

Angel, C., Sherman, L., Strang, H., Ariel, B., Bennett, S., Inkpen, N., Keane, A. and Richmond, T. (2014). Short-term effects of restorative justice conferences on posttraumatic stress symptoms among robbery and burglary victims: a Randomized Controlled Trial. Journal of Experimental Criminology, 10(3), 291-307.

point of departure. I wish to emphasise, however, that it is not my goal here to advocate the adoption or development of parallel justice. 
This is an Accepted Manuscript of an article published by Taylor \& Francis in Restorative Justice on 13 December 2017, available online: http://www.tandfonline.com/doi/full/10.1080/20504721.2017.1390999.

Bennett, C. (2008). The Apology Ritual: A Philosophical Theory of Punishment. Cambridge: Cambridge University Press.

Bolivar, D., Vanfraechem, I. and Aertsen, I. (2015). General Introduction. In I. Vanfraechem, D. Bolivar, and I. Aertsen, I. (eds.), Victims and Restorative Justice (pp. 1-11). London: Routledge.

Braithwaite, J. (1999). A Future Where Punishment is Marginalized: Realistic or Utopian? UCLA Law Review, 46, 1727-1750.

Cayley, D. (1998). The Expanding Prison: The Crisis in Crime and Punishment and the Search for Alternatives. Cleveland: Pilgrim Press.

Choi, J., Bazemore, G. and Gilbert, M. (2012). Review of research on Victims’ Experiences in Restorative Justice: Implications for Youth Justice. Children and Youth Services Review, 34(1), 35-42.

Christie, N. (1977). Conflicts as Property. British Journal of Criminology, 17(1), 1-15.

Coleman, C. and Moynihan, J. (1996). Understanding Crime Data: Haunted by the Dark Figure. Maidenhead: Open University Press.

Dignan, J. (2005). Understanding Victims and Restorative Justice. Maidenhead: Open University Press.

Ezendam, H. and Wheldon, F. (2014). Recognition of Victims’ Rights through EU Action. In Vanfraechem, I., Pemberton, A. and Mukwiza Ndahinda, F. (eds.) Justice for Victims: Perspectives on Rights, Transition and Reconciliation (pp. 51-65). Abingdon: Routledge.

Froestad, J. and Shearing, C. (2007). Conflict Resolution in South Africa: A Case Study. In G. Johnstone and D. Van Ness (eds.) Handbook of Restorative Justice (pp. 534-555). Cullompton: Willan.

Garland, D. (2001). The Culture of Control: Crime and Social Order in Contemporary Society. Oxford: Oxford University Press.

Gaudreault, A. (2005). The Limits of Restorative Justice, Proceedings of the Symposium of the Ecole Nationale de la Magistrature. Paris: Edition Dalloz.

Gavrielides, T. (ed.) (2014). A Victim-led Criminal Justice System: Addressing the Paradox. London: IARS Publications.

Green, S. (2007). The Victims’ Movement and Restorative Justice. In G. Johnstone and D. Van Ness (eds.) Handbook of Restorative Justice (pp. 171-191). Cullompton: Willan. 
This is an Accepted Manuscript of an article published by Taylor \& Francis in Restorative Justice on 13 December 2017, available online: http://www.tandfonline.com/doi/full/10.1080/20504721.2017.1390999.

Herman, S. (1999). 'The Search for Parallel Justice', Paper presented at the Restoration for Victims of Crime Conference, Melbourne.

Herman, S. (2010). Parallel Justice for Victims of Crime. Washington: National Center for Victims of Crime.

Hulsman, L. (1986). Critical Criminology and the Concept of Crime. Contemporary Crises, 10(1), 63-80.

Johnstone, G. (1996). Medical Concepts and Penal Policy. London: Cavendish.

Johnstone, G. (2007). Critical Perspectives on Restorative Justice. In G. Johnstone and D. Van Ness (eds.) Handbook of Restorative Justice (pp. 598-614). Cullompton: Willan.

Mika, H., Achilles, M., Halbert, E., Stutzman Amstutz, L. and Zehr, H. (2004). Listening to Victims - a critique of restorative justice policy and practice in the United States. Federal Probation, 68(1).

Ministry of Justice, UK (2012). Getting it Right for Victims and Witnesses. London: HMSO.

Pavlich, G. (2005). Governing Paradoxes of Restorative Justice. London: Glasshouse Press.

Poulson, B. (2003). A Third Voice: A Review of Empirical Research on the Psychological Outcomes of Restorative Justice. Utah Law Review, 2003:1 167-203.

Rossner, M. (2017). Restorative Justice in the Twenty-first Century: Making Emotions Mainstream. In A. Liebling, S. Maruna and L. McAra (eds) The Oxford Handbook of Criminology, Sixth Edition (pp. 967-989). Oxford: Oxford University Press.

Shapland, J., Robinson, G. and Sorsby, A. (2011). Restorative Justice in Practice: Evaluating What Works for Victims and Offenders. London: Routledge.

Strang, H. (2002). Repair or Revenge: Victims and Restorative Justice. Oxford: Oxford University Press.

Strang, H., Sherman, L., Angel, C., Woods, D., Bennett, S., Newbury-Birch, D. and Inkpen, N. (2006). Victim Evaluations of Face-to-face Restorative Justice Conferences, Journal of Social Issues, 62(2), 281-306.

Sullivan, D., Tifft, L. and Cordella, P. (1998). The Phenomenon of Restorative Justice: Some Introductory Remarks, Contemporary Justice Review, 1(1), 7-20.

Vanfraechem, I, Bolivar, D and Aertsen, I. (eds.) (2015). Victims and Restorative Justice. London: Routledge. 
This is an Accepted Manuscript of an article published by Taylor \& Francis in Restorative Justice on 13 December 2017, available online: http://www.tandfonline.com/doi/full/10.1080/20504721.2017.1390999.

von Hirsch, A., Ashworth, A. and Shearing, C. (2003). Specifying Aims and Limits for Restorative Justice: A ‘Making Amends’ Model? In A. von Hirsch, J. Roberts, A. Bottoms, K. Roach and M. Schiff (eds.) Restorative Justice and Criminal Justice: Competing or Reconcilable Paradigms? (pp. 21-41). Oxford: Hart.

Walgrave, L. (2008). Restorative Justice, Self-interest and Responsible Citizenship Cullompton: Willan Publishing.

Wright, M. (1986). Justice for Victims and Offenders: A Restorative Response to Crime (second edition). Winchester: Waterside Press.

Zehr, H. (2015). Changing Lenses: Restorative Justice for our Times (25 ${ }^{\text {th }}$ anniversary edition). Harrisonburg: Herald Press. 